\title{
Relation of Anthropometric Profile and Performance in Competition for Mexican High School Football Players on the Offensive Squad
}

\author{
Relación entre Perfil Antropométrico y Desempeño en la Competición para \\ Jugadores Juveniles Mexicanos de Futbol Americano de Posición Ofensiva
}

Martínez, A. E. ; Peñaloza, R.**; Lara-Padilla, E. ${ }^{* * *}$ \& Berral, J. F.****

MARTÍNEZ, A. E.; PEÑALOZA, R.; LARA-PADILLA, E. \& BERRAL, J. F. Relation of anthropometric profile and performance in competition for Mexican High School Football Players on the offensive squad. Int. J. Morphol., 32(3):1051-1059, 2014.

SUMMARY: The present study of Mexican high school football players on the offensive squad had the aim of determining the relation between their anthropometric profile, position on the team, and performance in competition. The study included 41 players from 15 to 18 years of age, studying and playing football at one of two high schools. Anthropometric measurements were taken (weight, height, diameter and perimeter of muscle areas) to determine the body mass index, body composition and somatotype. The results show that the anthropometric profile is related to performance (good/very good or poor/deficient), and that this relation depends on the position of the player. For linemen, good performance was associated with being tall, heavy and with a relatively high body fat percentage, and poor/deficient performance with a significantly lower height, lower weight and lower body fat percentage. For receivers and running backs, height did not appear to influence performance. For running backs, good performance was associated with heavy weight and a high body fat percentage. However for receivers, good performance was associated with a lower body fat percentage. The average somatotype for linemen was mesomorph-endomorph, for running backs meso-ectomorph, and for receivers mesomorph-ectomorph

KEY WORDS: Football; Body composition; Somatotype; BMI.

\section{INTRODUCTION}

Football has been practiced in Mexico since the end of the 19th century (Orellana, 2006; Morales, 1996). This sport is based on controlled physical contact, with specific rules designed to protect the players. The evolution of the rules and tactics of the game have led to the development of separate squads for offense and defense, as each requires distinct physical characteristics of the players.

The anthropometric profile of university and professional football players on the offensive squad has sparked interest among researchers from the United States and Japan (Bale et al., 1994, Harada et al., 2000; Wickkiser \& Kelly 1975; Smith \& Mansfield, 1984; Noel et al., 2003).
There have been no reports, to our knowledge, of the anthropometric profile of Mexican football players. Thus, the aim of the present study was to explore the anthropometric profile of football players on the offensive squad of two high school teams in Mexico, with the aim of determining the relation between a given somatotype (for each position) and performance in competition. Performance was evaluated based on 28 technical points proposed by a panel of three coaches (each with over 20 years of experience). The results should certainly be useful in the selection and training of these athletes (Vallejo, 2002; Canda et al., 1998; Salgado Sánchez et al., 2009; Rubio Pérez et al., 1993).

Máster en Alto Rendimiento Deportivo. Doctorando de la Universidad Pablo de Olavide, Sevilla. España

** Doctor en .Rendimiento Deportivo. Instituto Politécnico Nacional, Departamento de Estudios de Posgrado e Investigación. Escuela Superior de Medicina, México.

*** Doctor en Alto Rendimiento Deportivo. Instituto Politécnico Nacional, Departamento de Estudios de Posgrado e Investigación. Escuela Superior de Medicina, México.

***** Doctor en Medicina y Cirugía. Catedrático de Universidad. Responsable del Grupo de Investigación CTS-595. Universidad Pablo de Olavide, Sevilla, España. 


\section{MATERIAL AND METHOD}

Players. A transversal and descriptive study was conducted on 41 Mexican football players (between the ages of 15 and 18) from two different high school teams in Mexico City. Since the distribution of players by position was similar in the two schools (Table I; $\mathrm{p}=0.49$ ), a single group was formed for research purposes.

Table I. Distribution of the sample by position for Mexican high school football players.

\begin{tabular}{lcccc}
\hline Team/school & Linemen & Receivers & $\begin{array}{c}\text { Running } \\
\text { backs }\end{array}$ & Total \\
\hline CECyT \#7 & 8 & 10 & 2 & 20 \\
ENP \#1 & 10 & 7 & 4 & 21 \\
Total & 18 & 17 & 6 & 41 \\
\hline
\end{tabular}

CECyT No.7: Center for Scientific and Vocational Studies \#7 ("Vikings"). ENP No.1: National High School \#1 ("Broncos").

There were 10 hours of training with one game per week, during a period of six weeks. Additionally, a semifinal and final play-off game took place at the end of the season. The participants of the study were divided into three groups according to their position on the offensive squad: linemen $(n=18)$, receivers $(n=17)$ and running backs $(n=6)$. Anthropometric measurements were carried out in accordance with the ISAK protocol (Berral, 1995, 1996). Ethical norms for research on human beings, established by the Declaration of Helsinki (1975; updated most recently in 2008), were strictly followed.

Parameters. For weighing the players, a scale (TANITA, model HD 305) was employed that has a maximum capacity of $150 \mathrm{~kg}$ (with precision of $0.1 \mathrm{~kg}$ ) and a built-in height scale (with precision of $1 \mathrm{~mm}$ ). Each value is an average of three measurements taken on different days. An anthropometric apparatus (BERFER) was used and besides anthropometric index card.

Body composition was calculated by the Faulkner formula for athletes:

$$
\text { Body fat percentage }=5.782+0.153(\operatorname{tr}+\mathrm{sb}+\mathrm{se}+\mathrm{ab})
$$

where $\operatorname{tr}=$ triceps diameter, $\mathrm{sb}=$ subscapular diameter, $\mathrm{se}=$ supraspinal diameter, and $\mathrm{ab}=$ abdominal diameter.

BMI was calculated by the Quetelet formula:

$$
\mathrm{BMI}=\text { weight }(\mathrm{kg}) / \text { height }(\mathrm{m})^{2}
$$

Residual weight was calculated by the Würch formula:

$$
\text { Residual weight }=\text { total weight } \times 0.241
$$

Bone weight was calculated by the Martin formula:

Bone weight $=0.60 \times 0.0001 \times$ height $(\mathrm{cm}) \times$ (the sum of bone diameters)

where the sum of bone diameters $=$ humerus + femur + wrist + ankle.

Fat weight was calculated as the total weight times body fat percentage divided by 100 .

Muscle weight was calculated by the strategy of De Rose and Guimarães:

Muscle weight $=$ total weight - (fat weight + bone weight + residual weight)

The somatotype was calculated by the Heath \& Carter method (Berral, 1995, 1996; ISAK, 2001; Esparza, 1993; WHO, 2013).

Player performance (good/very good or poor/ deficient) was based on 28 technical points corresponding to the position played. These points were formulated by a panel of three coaches, each with more than 20 years of experience (Table II).

Statistical analysis. A data base of anthropometric parameters was elaborated on Excel. The results were analyzed by the software package SPSS.15.0 for Windows, based on the mean \pm SD of three measurements taken on different days. Normal distribution of data was tested with the Kolmogorov-Smirnov test. Average values were compared with one-way analysis of variance for normal distribution of data, and with Kruskal-Wallis for abnormal distribution of data. The contrast in variables for categories was carried out with the chi square test or the Fisher accuracy test. The relation between anthropometric data (according to position played) and performance in competition (good/ very good or poor/deficient) was analyzed with the linear model of general univariance, finding the best fit for independent variables. The position played was considered a dependent variable. A p-value $\leq 0.05$ was considered statistically significant for all statistical analysis.

\section{RESULTS}

The weight, height and BMI of each player are shown in Table III. The anthropometric characteristics are listed in 
Table IV. The most common somatotype was meso-ectomorp (24.4\%), with endo-mesoform and endo-ectomorph being less frequently found $(2.4 \%)$.

The average somatotype by position played was mesomorph-endomorph for linemen, mesomorph-ectomorph for receivers and meso-ectomorph for running backs.
Data was analyzed to determine if there is a relation between performance and anthropometric parameters (Table V). A notable relation was found between low BMI, low body fat percentage and poor performance for linemen and running backs, while low BMI and low body fat percentage was associated with good performance for receivers. Height was associated with good performance of linemen, but was

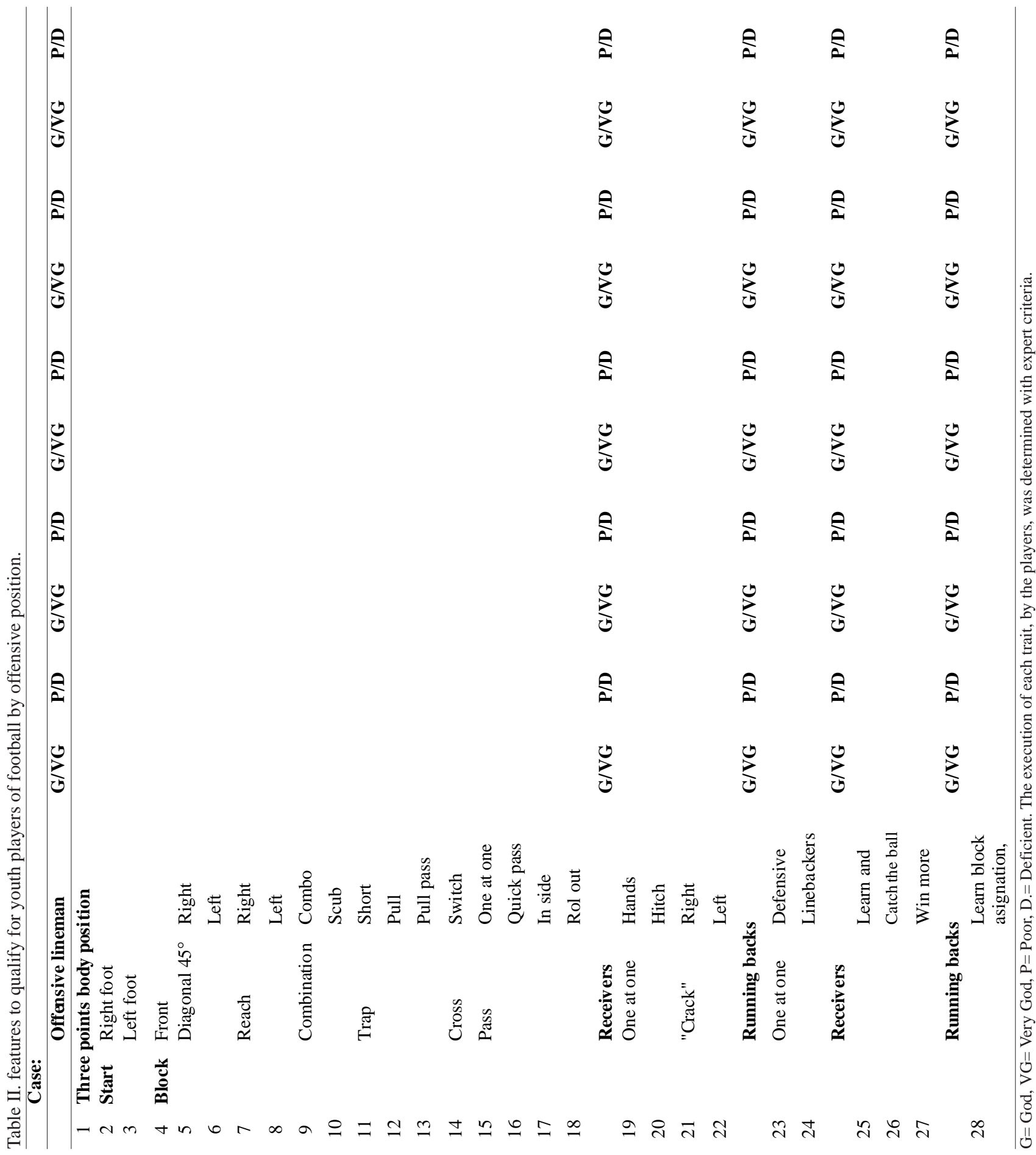


Table III. Weight, height and body mass index (BMI) of Mexican high school football players.

\begin{tabular}{lccccc}
\hline & n & Minimum & Maximum & Average & Density \\
\hline Weight & 41 & 51.1 & 115.9 & 70.88 & 14.73 \\
Height & 41 & 1.59 & 1.86 & 1.70 & 0.06132 \\
BMI & 41 & 18.50 & 36.58 & 24.17 & 4.078 \\
\hline
\end{tabular}

Table IV. Anthropometric characteristics of Mexican high school football players SPSS V15 for Windows.

\begin{tabular}{lcccc}
\hline \multicolumn{1}{c}{ Variable } & \multicolumn{2}{c}{ Position on the team } & Significance \\
& Linemen & Receivers & Running backs & P \\
\hline Weight & $82.8(13.9)$ & $61.0(6.3)$ & $62.9(5.0)$ & 0.0001 \\
Height & $1.72(0.06)$ & $1.69(0.06)$ & $1.68(0.04)$ & 0.0001 \\
BMI & $27.6(3.5)$ & $21.1(1.8)$ & $22.2(1.0)$ & 0.0001 \\
Body fat \% (Faulkner) & $16.3(2.7)$ & $10.0(1.3)$ & $9.5(0.7)$ & 0.0001 \\
Fat weight & $13.8(4.3)$ & $6.1(1.0)$ & $6.0(0.6)$ & 0.0001 \\
Muscle weight & $34.6(5.7)$ & $26.8(3.6)$ & $28.4(3.4)$ & 0.0001 \\
Bone weight (Martin) & $14.3(0.9)$ & $13.3(1.0)$ & $13.2(1.0)$ & 0.012 \\
Residual weight & $19.9(3.3)$ & $14.7(1.5)$ & $15.1(1.2)$ & 0.0001 \\
\hline
\end{tabular}

Table V. Weight, height and BMI in relation to overall health for football players.

\begin{tabular}{cccc}
\hline & $\begin{array}{c}\text { Average values for } \\
\text { Mexican high school } \\
\text { players 2009-2010 }\end{array}$ & $\begin{array}{c}\text { Average values for } \\
\text { U.S. university } \\
\text { players } \mathbf{1}_{\mathbf{9 7 5}}\end{array}$ & $\begin{array}{c}\text { Average values for US. } \\
\text { professional players }{ }^{+} \mathbf{1 9 7 5}\end{array}$ \\
\hline Weight & 70.88 & 88.38 & 107.00 \\
Height & 1.70 & 1.82 & 1.90 \\
BMI & 24.17 & 26.54 & 29.58 \\
BMI-Health & Normal/Healthy & Overweight & Overweight \\
\hline+ Wickiser \& Kelly $(1975)$ & &
\end{tabular}

+Wickkiser \& Kelly (1975)

not relevant to the performance of running backs and receivers.

The values for bone weight, residual weight and somatotype showed no relationship to performance for any given position. The variables most associated with good or poor performance were weight, fat weight, body fat percentage and BMI. The average value of these four parameters for each group was useful for determining which players did not have the somatotype related to good performance.

It was found that of 18 linemen, 17 (94.4\%) had characteristics that corresponded to good performance and one had characteristics corresponding to a running back. Three of 17 receivers shared characteristics with the running backs, and one of 6 running backs had the characteristics of a receiver. In general, $87.8 \%$ had the characteristics that were associated with good performance for their position, taking into account weight, height, BMI, percentage fat, muscle weight and somatotype.

Among players classified by the coaches as apt for their position (based on the 28 performance criteria), $100 \%$ had the anthropometric profile for their position that was associated with good performance. Of the 18 linemen, 4 were evaluated as unsuitable for their position according to their performance. Of these 4 , one was unsuitable for the position according to anthropometric parameters. Of 17 receivers, 5 were evaluated as unsuitable for their position according to their performance. Three of these 5 were unsuitable for their position according to anthropometric parameters. Of the 6 running backs, 3 were evaluated as unsuitable for their position according to their performance. One of these 3 was unsuitable for his position according to anthropometric parameters. 


\section{DISCUSSION}

Training directly affects body composition, tending to reduce the proportion of fatty mass and increase muscular mass. Diet can also influence the percentage of fat in case of a high caloric intake (Vallejo).

From 1975 to 2003, various studies were conducted in which body composition was calculated by the method of immersion in water and helium dissolution (Wickkiser \& Kelly; Smith \& Mansfield; Noel et al.; Wang et al., 1993). Air-displacement plethysmography (AP) with the BOD POD body-composition system (Life Measurement Instruments) (Kreamer et al., 2005) has also been employed, including height, weight, seven perimeter measurements of muscle areas, and four measurements of bone diameter. Upon applying regression equations, Wickkiser \& Kelly found significant differences between two groups of players in body density and body fat percentage- - one group was composed of the offensive and defensive line, and the other wide receivers, running backs and quarter backs. Additionally, these researchers used the BMI as an indicator of overweight, obesity and overall health (Table VI).

Years later, Smith \& Mansfield sought an equation that could predict body composition. However, with all equations tested the predicted and observed values differed significantly. The two equations that most closely approached the objective were among those cited by Smith \& Mansfield, one proposed by White, Mayhew and Piper for football players and the other by Jackson and Pollock for athletes in general. The problem with these two equations is that they overestimate body density in players with a relatively low real value of this parameter, and underestimate body density in players with a relatively high real value.

Note that our strategy for the fractionation tetracompatimental of the players has been more than acceptable, given that the average weight in the sample has been $68.7 \mathrm{~kg}$ (Table IV), in relation to the balance of 70.88 kilos (Table III)-average weight, what represents an acceptable error of $3 \%$.
During the 1980s and early 1990s, Noel et al., conducted a study in which they measured some anthropometric parameters of university football players, and then ten years later evaluated the same parameters of this group. They aimed to determine the increase in total body mass, the associated rise in body fat percentage, and changes in body composition. They reported an increase in body fat percentage that varied significantly according to the position played. In the offensive backfield (wide receivers, running backs and quarter backs) and defensive backfield, the increase in body fat percentage was less compared to that of offensive or defensive linemen (including tight ends). For the latter group there was a considerable increase in this parameter ( 25\%), which was not associated with economic status, level of education or ethnic origin. The majority of this body fat accumulated in the abdominal region, which is important when considering the high correlation that exists between abdominal obesity and circulatory disorders. Noel et al. recommended further study to determine the origin of this increase in body fat, with the aim of developing a followup program to assist these former players in their adjustment to life after retiring from football.

The magazine Parade published a report of U.S. high school football players considered to be the best in their position, based on a study that was carried out from 1963 to 1971 and 1972 to 1989 (Wang et al.). Compared to the players of the first period, they reported a much higher average value for the weight and BMI of players during the second period of the study, with no significant difference in height (Table VI). This finding generated national debate as to the nature of this increase in weight and BMI, with the aim of determining if the origin of the problem was due to a change in training, nutrition or drug abuse (especially anabolic steroids). Since the World Health Organization (WHO) considers a BMI of 25.9 to be the upper limit of the normal/healthy weight range, this increase from 29.51 to 32.12 was alarming. Interestingly, in the present study the weight of Mexican football players was at the upper limit of (but within) the healthy range according to the WHO.

Table VI. Weight, height and BMI for Mexican and U.S. football players in high school

\begin{tabular}{cccc}
\hline & $\begin{array}{c}\text { Average values for } \\
\text { Mexican high school } \\
\text { players 2009-2010 }\end{array}$ & $\begin{array}{c}\text { Average values for } \\
\text { U.S. high school } \\
\text { players 1963-1971+ }\end{array}$ & $\begin{array}{c}\text { Average values for U.S. } \\
\text { high school players } \\
\text { 1972-1989+ }\end{array}$ \\
\hline Weight & 70.88 & 102.38 & 114.51 \\
Height & 1.70 & 1.86 & 1.88 \\
BMI & 24.17 & 29.51 & 32.12 \\
\hline
\end{tabular}

+Wang et al (1993) 
Kreamer et al. conducted a study at the beginning of the training season with professional football players of the Indianapolis Colts. These researchers used equipment of the air-displacement plethysmography (AP) with the BOD POD body-composition system (Life Measurement Instruments), calculating average body fat percentage and the BMI according to the offensive position of the players. Players were categorized as tight ends, wide receivers, running backs, quarter backs, or linemen. They found the players to be overweight or obese in all positions. The only correlation between the aforementioned study and the current contribution was with offensive linemen, with Mexican players being overweight and American players obese (Tables VII, VIII and IX).

Table VII. Weight, height, \% fat, and BMI of football players.

\begin{tabular}{|c|c|c|c|c|}
\hline \multicolumn{5}{|c|}{ For U.S. professional players } \\
\hline Position & Height & Weight & Body fat \% & BMI \\
\hline Quarterback & 1.92 & 104.20 & 14.60 & 28.30 \\
\hline Running backs & 1.80 & 96.50 & 7.30 & 29.80 \\
\hline Wide receivers & 1.80 & 85.60 & 8.10 & 30.60 \\
\hline Tight ends & 1.94 & 115.60 & 15.10 & 30.90 \\
\hline Offen sive linemen & 1.93 & 140.00 & 25.10 & 37.10 \\
\hline \multicolumn{5}{|c|}{ For Mexican high school players } \\
\hline Position & Height & Weight & Body fat \% & BMI \\
\hline Running backs & 1.68 & 63.0 & 9.55 & 22.23 \\
\hline Receivers & 1.70 & 61.1 & 10.04 & 21.2 \\
\hline Linemen & 1.73 & 82.88 & 16.39 & 27.63 \\
\hline
\end{tabular}

+ Kreamer et al (2005).

Table VIII. BMI and \% fat in relation to the overall health of football players according to position on the team.

\begin{tabular}{lcc}
\hline \multicolumn{3}{c}{ For U.S. professional players } \\
\hline Position & Body fat \% & BMI \\
\hline Quarterbacks & Healthy & Overweight \\
Running backs & Healthy & Obese \\
Wide receivers & Healthy & Obese \\
Tight ends & Healthy & Obese \\
Linemen & In poor health & Severely obese \\
\hline For Mexican high school players & \\
\hline Position & Body fat \% & BMI \\
\hline \multicolumn{3}{c}{ Running backs } \\
Receivers & Healthy & Nomal/healthy \\
Linemen & Healthy & Nomal/healthy \\
\hline+ Kreamer et al (2005). & Healthy & Overweight \\
\hline
\end{tabular}

Table IX. Weight, height, BMI, \% fat in relation to position on the football team.

\begin{tabular}{lcccc}
\hline \multicolumn{5}{c}{ Mexican high school players } \\
\hline Position & Weight & Height & BMI & \% fat (Faulkner) \\
\hline Running backs & 63.00 & 1.68 & 22.23 & 9.55 \\
Receivers & 61.10 & 1.70 & 21.20 & 10.04 \\
Offensive linemen & 82.88 & 1.73 & 27.63 & 16.39 \\
\hline U.S. profesional players+ & & & & \\
\hline Position & Weight & Height & BMI & \% fat (Faulkner) \\
\hline Running backs & 96.50 & 1.80 & 29.8 & 7.3 \\
QB Quarterback & 104.20 & 1.92 & 28.3 & 14.6 \\
WR Wide receivers & 85.60 & 1.80 & 30.6 & 8.1 \\
TE Tight ends & 115.60 & 1.94 & 30.9 & 15.1 \\
Offensive linemen & 140.00 & 1.93 & 37.1 & 25.1 \\
\hline
\end{tabular}

+ Kreamer et al (2005). 
In a study by Kaiser et al. (2008), anthropometric data were compared between football players in the first year of the university and professionals in the NFL (National Football League), finding the university players to be taller and lighter in weight. The BMI and body fat percentage were compared according to the position played, and differences in the method of training and diet were taken into account, as was the greater rigor of professional sports.

Physical exercise normally allows for the maintenance of weight and body composition at healthy levels (Hill \& Wyatt, 2005; Jakicic \& Otto, 2005). It is important to continue researching the phenomenon of overweight and obesity in people who regularly do exercise (e.g., football players in the United States), because the BMI is associated with the fat content of the body (Garrido \& González, 2004), which in cases of overweight and obesity imply health risks such as cardiovascular disorders, ischemia, diabetes, metabolic syndrome, injuries to the muscularskeletal system, and cognitive problems due to concussion (Garrido \& González; Hill \& Wyatt; Jakicic et al.; Haskell et al., 2007; Mazic et al., 2009; Ode et al., 2007; Harp \& Hecht, 2005; George et al., 2003; Mathews \& Wagner et al., 2008; Garry \& McShane, 2001; Millard-Stafford et al., 1989; Baron \& Rinsky, 1994).

Mazic et al. reported significant differences in body fat percentage between trained and untrained healthy male university students. Ode et al. studied trained and untrained university students, all participating in some sports activity. These researchers showed that the BMI should be used cautiously in terms of classifying athletes and non-athletes as overweight or obese. They suggested a different BMI scale for athletes.

In this sense, the BMI and weight of football players should be studied in order to determine their body composition. For instance, it would be interesting to study the body composition of the over $25 \%$ of NFL football players who, according to present standards, are placed in the category of type II obesity. Harp \& Hecht pose that the high BMI value of these players likely reflects a healthy increase in muscle mass, these players being subject to intense pressures to accumulate muscle tissue.

The Mexican football players of the present study had a BMI within the healthy range. However, it is necessary to continue to monitor their anthropometric parameters as a preventative measure. Additionally, by continuous monitoring of these parameters, rooky players could be better oriented to the position in which their performance should be better. In the same sense, young athletes (8-14 years old) participating in the school pentathlon could be oriented by similar testing for physical aptitude in the 1000 meter race, the 50 meter dash, push-ups, sit-ups, and number of halfsit-ups in 60 seconds. Or alternately, the Cooper Test could be employed, which includes the 40 yard dash, broad jump, vertical jump (Sargent-Lewis), bench press 3RM (80\%) and the Illinois agility test.

It is important to resolve the issue of the correct standard for overweight and obesity in athletes with high levels of muscle mass. With well-established standards appropriate for each sport and position on the team, the appropriate player selection, training, and diet could be established to attain maximum performance.

\section{CONCLUSION}

A close association was observed between the anthropometric characteristics of Mexican football players, their position on the offensive squad, and their performance (evaluated according to criteria developed by experienced coaches) in competition. This information could be useful in the selection and training of players for distinct positions, with the aim of improving performance in competition.

\section{ACKNOWLEDGMENTS}

We thank the academic and sports authorities of the Centro de Estudios Científicos y Tecnológicos No. 7 "Cuauhtémoc" (Cuauhtemoc Center for Scientific and Vocational Studies \#7), as well as those of Escuela Nacional Preparatoria No. 1 "Gabino Barreda" (Gabino Barreda National High School \#1). We also thank all the players that participated in the present study. Thanks to Dr. Saúl Renán León Hernández for his invaluable collaboration.

MARTÍNEZ, A. E.; PEÑALOZA, R.; LARA-PADILLA, E. \& BERRAL, J. F. Relación entre perfil antropométrico y desempeño en la competición para jugadores juveniles mexicanos de futbol americano de posición ofensiva. Int. J. Morphol., 32(3):1051-1059, 2014.

RESUMEN: El objetivo de este trabajo fue determinar la relación entre los perfiles antropométricos de jugadores juveniles mexicanos de futbol americano y su desempeño en la competición, tomando en cuenta su posición ofensiva en el juego. Se estudiaron 41 jugadores de 15 a 18 años de edad, de nivel bachillerato de dos instituciones educativas. Se registraron medidas antropométricas (peso, estatura, pliegues, diámetros y perímetros) para determinar el índice de masa corporal, la composición corpo- 
ral y el somatotipo. Nuestros resultados muestran que el perfil antropométrico de los jugadores estuvo relacionado con su desempeño (bueno/muy bueno o malo/deficiente) en su posición ofensiva en el juego. La estatura fue un factor importante en el caso de los linieros, ya que los clasificados como malos/deficientes para esa posición, tuvieron una talla significativamente más baja que los buenos/muy buenos; sin embargo, ésta no parece influir como criterio para clasificar a receptores y corredores. Se encontró que los linieros ofensivos fueron los jugadores más altos y pesados y con mayor porcentaje de grasa, seguidos de los receptores y por último de los corredores. En esta posición, los malos/deficientes fueron los de menor peso, y los buenos/muy buenos fueron los de mayor porcentaje graso, al igual que en la posición de corredores. Sin embargo en los receptores la relación se invierte, ya que los buenos/muy buenos fueron los de menor porcentaje graso. El somatotipo medio por posición fue mesomorfo-endomorfo para los linieros, mesomorfo-ectomorfo para los receptores y mesoectomorfo para los corredores.

PALABRAS CLAVE: Fútbol americano; Composición corporal; Somatotipo; IMC.

\section{REFERENCES}

Bale, P.; Colley, E.; Mayhew, J. L.; Piper, F. C. \& Ware, J. S. Anthropometric and somatotype variables related to strength in American football players. J. Sports Med. Phys. Fitness, 34(4):383-9, 1994.

Baron, S. \& Rinsky, R. NIOSH Mortality Study of NFL football players: 1959-1988. Cincinnati, Centers for Disease Control, National Institute for Occupational Safety and Health, 1994.

Berral, F. J. Cineantropometría: Concepto. Aspectos anatómicos de interés. Planos y ejes. Puntos anatómicos de referencia. Med. Ejerc., 10(2):21-33, 1995.

Berral, F. J. Cineantropometría: Mediciones antropométricas. Parte II. Med. Ejerc., 11(1):19-30, 1996.

Canda, A. S.; Cabañero, M.; Millán, M. J. \& Rubio, S. Perfil antropométrico del equipo Nacional Español de Rugby: comparación entre los puestos de juego. Med. Sport, 51(1):29-39, 1998.

Esparza, F. Manual de Cineantropometría. Pamplona, Femede, 1993.

Garrido, C. R. P. \& González, L. M. Indice de masa corporal y composición corporal. Un estudio antropométrico de 2500 deportistas de alto nivel. Buenos Aires, Efdeportes.com, 2004. Disponible en: http://www.efdeportes.com/efd76/antrop.htm

Garry, J. P. \& McShane, J. J. Analysis of lipoproteins and body mass index in professional football players. Prev. Cardiol., 4(3):103-8, 2001.
George, C. F.; Kab, V. \& Levy, A. M. Increased prevalence of sleepdisordered breathing among professional football players. $N$. Engl. J. Med., 348(4):367-8, 2003.

Harada, H.; Hamabe, H. \& Koizumi, K. The effect on body composition by physical training for football players on university level. Bull. Nippon Vet. Anim. Sci. Univ., 49:46$50,2000$.

Harp, J. B. \& Hecht, L. Obesity in the National Football League. JAMA, 293(9):1061-2, 2005.

Haskell, W. L.; Lee, I. M.; Pate, R. R.; Powell, K. E.; Blair, S. N.; Franklin, B. A.; Macera, C. A.; Heath, G. W.; Thompson, P. D. \& Bauman, A. Physical activity and public health: updated recommendation for adults from the American College of Sports Medicine and the American Heart Association. Med. Sci. Sports Exerc., 39(8):1423-34, 2007.

Hill, J. O. \& Wyatt, H. R. Role of physical activity in preventing and treating obesity. J. Appl. Physiol. (1985), 99(2):765-70, 2005.

Jakicic, J. M. \& Otto, A. D. Physical activity considerations for the treatment and prevention of obesity. Am. J. Clin. Nutr., 82(1 Suppl.):226S-229S, 2005.

Kaiser, G. E.; Womack, J. W.; Green, J. S.; Pollard, B.; Miller, G. S. \& Crouse, S. F. Morphological profiles for first-year National Collegiate Athletic Association Division I football players. J. Strength Cond. Res., 22(1):243-9, 2008.

Kraemer, W. J.; Torine, J. C.; Silvestre, R.; French, D. N.; Ratamess, N. A.; Spiering, B. A.; Hatfield, D. L.; Vingren, J. L. \& Volek, J. S. Body size and composition of National Football League players. J. Strength Cond. Res., 19(3):4859, 2005.

Mazic, S.; Djelic, M.; Suzic, J.; Suzic, S.; Dekleva, M.; Radovanovic, D.; Scepanovic, L. \& Starcevic, V. Overweight in trained subjects - are we looking at wrong numbers? (Body mass index compared with body fat percentage in estimating overweight in athletes.). Gen. Physiol. Biophys., 28:200-4., 2009.

Mathews, E. M. \& Wagner, D. R. Prevalence of overweight and obesity in collegiate American football players, by position. J. Am. Coll. Health, 57(1):33-8, 2008.

Millard-Stafford, M.; Rosskopof, L. B. \& Sparling, P. B. Coronary heart disease: risk profiles of college football players. Physician Sports Med., 17(9):150-63, 1989.

Morales, T. A. 100 años de futbol americano en México. México D.F., Editoriales Juveniles, 1996.

Noel, M. B.; VanHeest, J. L.; Zaneteas, P. \& Rodgers, C. D. Body composition in Division I football players. J. Strength Cond. Res., 17(2):228-37, 2003. 
MARTÍNEZ, A. E.; PEÑALOZA, R.; LARA-PADILLA, E. \& BERRAL, J. F. Relation of anthropometric profile and performance in competition for Mexican High School Football Players on the offensive squad. Int. J. Morphol., 32(3):1051-1059, 2014

Ode, J. J.; Pivarnik, J. M.; Reeves, M. J. \& Knous, J. L. Body mass index as a predictor of percent fat in college athletes and nonathletes. Med. Sci. Sports Exerc., 39(3):403-9, 2007.

Orellana Suárez, J. G. ¿Cuándo y por qué surgió el fútbol americano en México? Buenos Aires, Efdeportes.com, 2006. Disponible en: http://www. efdeportes.com/efd100/futam.htm

Rubio Pérez, F. J.; Bonafonte, L. F.; Peral Martínez, R. \& Boqué Cavallé, M. Perfil antropométrico y funcional del jugador de hockey sobre patines. Apunts, 30:23-9, 1993.

Salgado Sánchez, I.; Sedano Campo, S.; De Benito Trigueros, A.; Izquierdo Velasco, J. M. \& Cuadrado Sáenz, G. Perfil antropométrico de jugadoras de baloncesto españolas, Análisis en función del nivel competitivo y de la posición. Int. J. Sport. Sci., 5(15):1-16, 2009.

Smith, J. F. \& Mansfield, E. R. Body composition prediction in university football players. Med. Sci. Sports Exerc., 16(4):398405,1984

The International Society for the Advancement of Kinanthropometry (ISAK). International Standards for Anthropometric Assessment. Unerdale, ISAK, 2001.

Vallejo, C. L. Desarrollo de la condición física y sus efectos sobre el rendimiento físico y la composición corporal de niños futbolistas. Tesis Doctoral. Barcelona, Universidad Autónoma de Barcelona, 2002.

Wang, M. Q.; Downey, G. S.; Perko, M. A. \& Yesalis, C. E. Changes in body size of elite high school football players: 1963-1989. Percept. Mot. Skills, 76(2):379-83, 1993.

Wickkiser, J. D. \& Kelly, J. M. The body composition of a college football team. Med. Sci. Sports., 7(3):199-202, 1975.

World Health Organization. México: health profile, 2013. Disponible en: http://www.who.int/gho/countries/mex.pdf
Correspondence to:

Alejandro Efraín Martínez Moreno, M.C. Cereales 204, Col. Valle del Sur, C.P. 09819, Ciudad de México

MÉXICO

Email: alejandroefrainmm@gmail.com

Received: 01-07-2013

Accepted: 02-05-2014 